\title{
Lived Experiences of Repeat Crime Offenders: A Phenomenological Untold Stories
}

\author{
$1^{\text {st }}$ Angelo P. Alob \\ College of Criminal Justice Education \\ Northern Negros State College of \\ Science and Technology \\ Philippines \\ angelo100578@gmail.com
}

\author{
$2^{\text {nd }}$ Jayson A. Dela Fuente \\ Northern Negros State College of Science \\ and Technology \\ Philippines \\ delafuentejayson@nonescost.edu.ph
}

https://doi.org/10.48161/qaj.v1n4a84

\begin{abstract}
Recidivism is an offense committed by an individual who at the time of the trial has been previously convicted by final judgment of another crime. The perspective motivates the researchers to explore the lived experiences and to discover the untold stories of repeat crime offenders which shed light on the informants' experiences in the pillars of the criminal justice system, the impact of incarceration on the lives of the offender, and the reasons for reoffending. Qualitative research using a phenomenological approach was used through an in-depth individual face-to-face interview and focus group discussion with ten recidivists and inmates in selected city jails in Negros Occidental Philippines who are purposively qualified based on the inclusion criteria set by the researchers. Data was collected using the audiotape recorded interviews with the informants. The responses were transcribed from the interviews and analyzed to capture and describe the richness of the informants' experiences. The findings revealed six major themes which emerged after the rigorous data explication. The Cry of the Suspect, Light within Darkness, You Reap what you Sow, Blessing in Disguise, Many are Bad Associates But Few are Good Mentors, and Corruption of the Mind. Key findings suggest: Firstly, to have a strong foundation, effective and efficient coordination and cooperation among the pillars of the criminal justice system. Secondly, establish a systematic, comprehensive, and sustainable rehabilitation program with strict and vibrant implementation, monitoring, and evaluation to ensure its success.
\end{abstract}

Keywords-Lived Experiences, Phonological Study, Repeat Crime Offenders, Untold Stories

\section{INTRODUCTION}

Recidivism is an offense committed by an individual who at the time of the trial has been previously convicted by final judgment of another crime articulated in article 14 paragraph 9 of the Revised Penal Code of the Philippines. [1] clearly defined as a repetitious criminal act or simply a repeat offense. Globally, it was recorded that from $67.8 \%$ $(404,638)$ state prisoners released in 2005 in 30 states it elevates to almost $76.6 \%$ within the last 3 to 5 years. The status quo revealed that among the prisoners released from 23 states $49.7 \%$ and $55.1 \%$ had either parole or probation violation or an arrest for a new offense [2]. In the Philippines, from the first two months of his Excellency President Rodrigo Roa Duterte in 2016, the Philippine National Police (PNP) Women and Children Protection Center (WCPC) reported that 20,584 minors have surrendered to local police offices of which 729 are from Negros Occidental. Based on the police record, $65 \%$ $(13,000)$ are first-time offenders and about $8 \%(1,595)$ were repeat offenders. Despite the rehabilitation and treatment programs of the government, repeat offenders are still a perennial problem in society. The given phenomenon motivates the researchers to capture the lived experiences and untold stories of repeat crime offenders with the end view of the proposed intervention to minimize the repeat offenders.

\section{BACKGROUND THEORY}

The deterrence theory, social bond theory, and labeling theory support where the study is anchored. Deterrence is the omission or curtailment of a crime from fear of legal punishment [3]. It identified two possibilities in which people may either refrain to commit the crime or to have fear the legal punishment. The deterrence theory is not universally accepted. However, there is a proposition that the greater the certainty, severity, and celerity of legal punishment for any crime committed of an individual the less rate it would be. Recently, the deterrence theory includes extra-legal punishments such as shaming and community service among others [4]. On the other side [5] believes that there is a need to incorporate nondeterrence 
variables that are also related to crime like stigma. [6] conveyed that a social bond theory portrays an individual's tendency to infringe upon the law which is an after-effect of looking for gratification. The social bond theory argues that strong bonds to family, friends, and community works to compel tendencies to commit any crime [7]. [8] believed that social bond is the connection between the individual and society. This theory posits that deviance transpires when a social bond does not exist. The social bond theory is one of the dominant perspectives on deviant behavior and probably the most frequently tested and discussed sociological theories [9]. Individuals with strong attachments according to [10] are less likely to engage in deviant behavior who further emphasized that the attachment of the young individuals to parents has significant importance. The quality of communication with parents is a major indicator of parental attachment. Commitment is another social bond component that pertains to the investment to different resources in conventional undertakings which represent the stakes in conformity [9].

\section{LITERATURE REVIEW}

The social bond theory posits that individuals with strong commitments will not jeopardize engaging in any deviant act. Moreover, it was pointed out that individuals' involvement in conventional pursuits spared the engagement in deviant behavior. The labeling theory focuses on the consequences of the societal reaction that a deviant behavior receives. Society labels and stigmatizes the deviant which resulted in self-esteem [11]. The theory is rooted in [12] who strongly argued that people become deviant because society labeled them as unwanted and unworthy. Accordingly, [13] believed that deviance is not determined by the behavior itself but the reaction the behavior receives when it is observed through the approved and legal point of view. This was supported by [14] that the marginalization of the labeled individual is the reflection of the one who labeled the deviant. [15] believed that when a certain individual engaged in criminal behavior it will result in the likelihood to continue committing the crime throughout the life-course. This antisocial persistent behavior of criminals on repeating the crime is considered as the static characteristics manifested in the predestination at an early age [16]. The basic variables that explain recidivism are accounted for the initiation of criminal behavior. The standpoint portrays that individuals develop the norms that favor crime and consequently recidivate the crime. Delinquents will cease their engagement in crime as their identity changes [17]. [18; 19] pointed out that the age-crime curve can be disaggregated into groups due to etiological differences and offending trajectories. This was emphasized by [20] that a human being is a social animal in which the existence of the strongest motivations may come from person to person. Similarly, the life-course approaches to understand the behavior of criminals provide salient points as to social relationships [21]. The presence of a social network protects the individual from a variety of negative stimuli and subsequently can help reduce recidivism [22].
Generally, the expectation is that individuals with a support network from different stakeholders have strong coping strategies for challenges associated with reentry into society $[23 ; 24]$. The different theoretical perspectives anticipate that inmate social ties can prevent or reduce offending or committing crimes [25]. The stronger the ties to family and work, the less criminal behavior [26]. The experience of imprisonment may reduce the incarcerated offender's legal prospects by eliminating pathways for conventional development [27]. Moreover, when areas of social control are reduced, offenders have a smaller incentive to abstain from reoffending. This mechanism has been supported in a Canadian study on 86 homicide recidivists that reduction of family and community support after prison release explained why some homicide offenders recidivated while others did not [28]. In a qualitative study with street crime opportunists by [25], he found out that identity deconstruction is necessary to change a long-term process of resistance. However, this is not a known transformation that can be applied to homicide offenders. Rather than focusing on identity change, [29] believed that cessation of various forms of crime due to biological and psychological factors drives the offenders to commit repeatedly the crime. In terms of homicide recidivism, the decline in these factors coincides with the peak and decrease in the overall deviant behavior. Based on this perspective, it would be expected that homicide offenders who are older at the time of release would be less likely to re-offend [30]. Therefore, younger age at release increases the likelihood to recidivate [31]. This was supported by [32] that gang-affiliated juvenile homicide offenders were more likely to recidivate compared to juveniles without such affiliations. [33] found out that partial support for this static approach to recidivism stating that juveniles who lacked self-control were more likely to recidivate than those who did not possess these static risk factors. Sexual offense recidivism was best predicted by measures of sexual deviancy and to a lesser extent by general criminological factors [34]. Those offenders who failed to complete treatment were at higher risk for reoffending than those who completed treatment. The predictors of nonsexual violent recidivism and general recidivism were similar to those predictors found among nonsexual criminals. This study finds support from [35] which noted that the ability to predict sexual and violent recidivism of rapists was poor. More sexual recidivists, compared with non-recidivists, had been removed from their family home before age 16 . Violent recidivists compared with non-recidivists were also more frequently removed from their homes before 16 years of age, and they showed significantly more problems with alcohol. In terms of any criminal recidivism, recidivists compared with nonrecidivists were younger and scored higher on the Michigan Alcohol Screening Test (MAST). They also had more previous charges and or convictions for violent offenses and more charges and or convictions for any criminal acts.

The combination of age and MAST scores was able to predict $92.6 \%$ of the nonrecidivists and $53.3 \%$ of the recidivists. The outstanding feature of the total group of rapists was their poor sexual adjustment as indicated on the Derogatis Sexual Functioning Inventory (DSFI), on which 
they scored at approximately the seventh percentile of the population at large. There was also an indication that rapists have problems with hostility as measured by the BussDurkee Hostility Inventory (BDHI). Furthermore, the range of scores on the MAST indicated that the total group of rapists has serious problems with alcohol. According to [36] those who return to disadvantaged neighborhoods recidivate at a greater rate than those who return to resource affluent communities recidivate at a lesser rate. Whilst, [37] found out that unemployment and public negative attitudes towards ex-prisoners were among the factors which lead to recidivism. This was supported by [38] that having a community member with negative perceptions about recidivists and have a stigma and discrimination in areas such as employment, housing, and romantic relationships. In terms of predictors of personality, [39] found that the most important predictors of both forms of recidivism were psychopathic traits. However, in the sample of convicts with higher intensity and variety of criminal behavior, the most important predictors of the number of sentences were anti-sociality and a morality induced by frustration, while the most important predictors of the number of prison sanctions were amorality induced by brutality and disintegration. Likewise, [40] found out that psychopaths continued to recidivate at a higher rate than nonpsychopaths even beyond age 40. On the other hand, [41] emphasized that recidivism is more likely to include youth with a previous conduct disorder diagnosis, a self-reported previous suicide attempt, age, and the number of court offenses. Conversely, predictors that made recidivism less likely include race a previous attention-deficit hyperactivity disorder diagnosis, and a misdemeanor conviction. The intensive literature reviews by the researchers shed light to determine the gap. There are various approaches and studies conducted related to repeat crime offenders. The works of literature and studies focus purely on predictors for a particular crime such as sexual offense, murder, and homicide while others on the different factors that contribute to recidivism, the life experiences of the offenders after their release in the community using the quantitative approach of research.

\section{METHODS}

\section{Research Design}

The researchers utilized a qualitative research design using a phenomenological approach. This is deemed to be the most suitable as it sought to understand a given research problem or phenomenon from the experiences lived and told by the informants [42]. It is used to gain and understand the underlying reasons, opinions, and motivations. A phenomenological approach is being employed to vividly describe the lived experiences of individuals about a certain phenomenon [43].

\section{Research Environments}

The study was conducted in Negros Occidental specifically in the cities of Bacolod, Sagay, and Escalante. Negros Occidental is known as the "sugarbowl of the Philippines," as it produces more than half the nation's sugar production. Fishing is one of the sources of income. The primary spoken language is Hiligaynon (also known as Ilonggo). With a population of $2,497,261$, it is the most populated province in Negros Occidental, the second-most-populous province in the Visayas after Cebu, and the eighth mostpopulous province of the Philippines.

In 2014, Negros Occidental is the province with the highest income in the Philippines, earning an average of P3.332 billion. It is composed of 7 districts including Bacolod City as the lone district and 12 Cities with a total land area of $7,802.54$ square kilometers (3,012.58 sq mi). If Bacolod City is included for geographical purposes the province has an area of 7,965.21 square kilometers (3,075.38 sq mi). Bacolod City is a highly urbanized city in the Philippines. It is the capital of the province of Negros Occidental where it is geographically situated but governed administratively independent from it. Having a total of 561,875 inhabitants as of the 2015 census, it is the most populous city in the Western Visayas and the second most populous city in the Visayas after Cebu City. It is the center of the Bacolod metropolitan area, which includes the cities of Silay and Talisay with a total population of 791,019 inhabitants along with a total area of $578.65 \mathrm{~km} 2$ (223.42 sq mi). Bacolod is the Philippines' third fastest growing economy in information technology (IT) and business process outsourcing (BPO) activities. The City of Sagay is a 3rd class city in the province of Negros Occidental, Philippines. According to the 2015 census, it has a population of 146,264 people. Sagay can be identified in the map of Negros Occidental because of its "ice-cream cone" shape sliced from the northern tip of Negros. The name of the city comes from the semi-spherical shell called "sigay," which can be found in the area. Escalante, officially the City of Escalante, is a 4th class city in the province of Negros Occidental, Philippines. According to the 2015 census, it has a population of 94,070 people. Escalante was converted into a component city of Negros Occidental when its charter, R.A. 9014 was signed into law on February 28, 2001, by President Gloria Macapagal-Arroyo, which was subsequently ratified in a plebiscite on March 2001.

Key Informants

The informants of the study were the ten recidivists and inmates in selected city jails in Negros Occidental Philippines who are purposively qualified based on the inclusion criteria set by the researchers. Four of the informants ( 2 from Sagay and 2 from Escalante) were individually interviewed while six (2 from Sagay and 4 from Bacolod) were included in the focused group discussion.

\section{Research Instrument}

A researcher-made phenomenological interview guide was used as the primary data gathering instrument to understand the lived experiences and untold stories of repeat offenders. It is comprised of three parts: Part I, dealt with the lived experiences of the repeat offenders in the pillars of the criminal justice system. This includes the positive and negative experiences of the informants in law enforcement, prosecution, court, correction, and community. Part II dealt with the informant's views on the impact of incarceration. This includes the positive and negative impact of incarceration on the lives of the informants including their families. Part III dealt with the informant's views on the 
reasons for re-offending. This includes the factors that drive the informants to re-offend. Validity in qualitative research refers to the extent to which an account accurately represents the social phenomena to which it refers [44]. The researchers subjected the interview guide for the face and content validity by the three (3) panels of experts in the qualitative research and the field of criminal justice education. Whilst, reliability in qualitative research refers to the level of consistency with which cases are assigned to a similar category by various observers or by the same observer on numerous occasions [45]. For reliability, the researchers made sure that the transcriptions were precise and considered the consistency of the responses/answers of the informants using the inter-rater reliability. The researchers asked three professionals in the field of guidance and counseling to assess the codes obtained in the data. The organization and uniformity of the results were evaluated and established among the raters.

\section{Data Collection}

In gathering the data, the researchers conducted personal audio-recorded interviews using a handheld recorder. The informants were given time to decide if wanted to be interviewed. The interviews were scheduled at the convenience of the informants upon allowing the researchers to interview them. The interview was conducted in dialect "Hiligaynon" a language that the informants are comfortable with and easily understood. During the interview, the informants were given a consent form and the interviewer explained the content as well as the schedule and flow of the interviews. The researchers explained to the informants the purpose and format of the interview and terms of confidentiality were discussed to maintain their complete anonymity. The researchers also provided the informants their contact information for possible clarifications for ambiguous responses during the interview.

\section{Data Analysis}

In analyzing the data from selected ten (10) informants, the researchers employed [46] method as used by [42] which conducted various analyses and enthused deeper into understanding the data. Representing the data and interpreting the larger meaning of the data that are essential and being studied which are the lived experiences and untold stories of repeat offenders. Frequent taking down notes helped in identifying statements and propose ways in coding data. In the study, important statements, originally (if in vernacular were preserved and translated for readers' needs). The interview process was audio recorded. Based on the responses of the participants, the researchers can verify the themes.

\section{Ethical Considerations}

The ethical principles adhered to in the study include informed consent, confidentiality and anonymity, beneficence and non-maleficence, and justice. Written informed consent forms were also presented to the participants. The interviewers reiterated participants' right to withdraw and skip inappropriate questions. It was emphasized that the interview would be audio recorded and that the data gathered in the interview would be used for academic purposes only. The researchers assured the informants that the information gathered in the interview would be strictly confidential and anonymity of their identities would be constantly maintained. The study used code names to conceal participants' identities. Recordings were also kept to aid in the transcription of their verbatim accounts. The researchers also ensured that the possible beneficial effects of the study outweighed its possible harmful effects and that the results may help the victims as well as other members of the community. Following an interview, a short debriefing session was facilitated by the researchers. This allowed the informants to process their narratives.

\section{Trustworthiness of Research}

To ensure the trustworthiness of the results, the researchers went through the rigorous processes of credibility, dependability, transferability, and confirmability. The credibility of the study is the top priority of this research. Information from the interview and observation session must be kept confidential at all times, and be used only for the success of the main purpose of this study. This study will be conducted with credibility over its result. Biases over the interpretation will be avoided to make this study reliable. The informants were allowed to express their ideas and feelings whether the content of the output is based on what they intend to tell. After the study, the researchers went back to the informants and asked their reactions about the result to see to it that it would show their intention. The dependability of the study was also considered. Any changes in the setting of research were accounted for and described these changes, how it affects the way the research approaches the study. From the start of the study until it ended, the researchers took careful steps in ensuring that the procedures were followed based on research methods. The whole process and activities of this study were reviewed by independent auditors. Transferability was one of the priorities of the research. The collected data were generalized based on the context and setting of the research. It involves thinking through what kind of relationship these study findings have to other populations and settings and unpacking exactly what inferences can be drawn from the data analysis. Confirmability of the study started with seeking the approval of the participants to pursue the conduct of the project. It included their full consent as a participant through the individual consent form. They had signed the said form as an indication of their consent to participate in the study. The interview guide was explained and narrated by its details and full descriptions that which answers the main purpose of this study. Aside from this, the informants were provided with copies of the interview guide for their proper reference.

\section{FINDINGS AND DISCUSSION}

This study presents the data with an empirical method through a phenomenological approach. It includes the full description of all informants' statements from the audiorecorded interviews. The significant statements that reflect the essential lived experiences of repeat offenders were then selected. The researchers transcribed the details of the interviews with full protection of the identity of the informants through hiding their real names in alias. To have 
a clearer picture of the lived experiences of the informants, the local dialect of the informants was taken into account to allow a free expression of their untold experiences. Their responses were translated into English for general readability. The researchers extracted the significant statements of the informants through the use of horizontalization. Then core meanings were formulated and were grouped into cluster themes. The cluster themes were then grouped to form meaningful emergent themes.
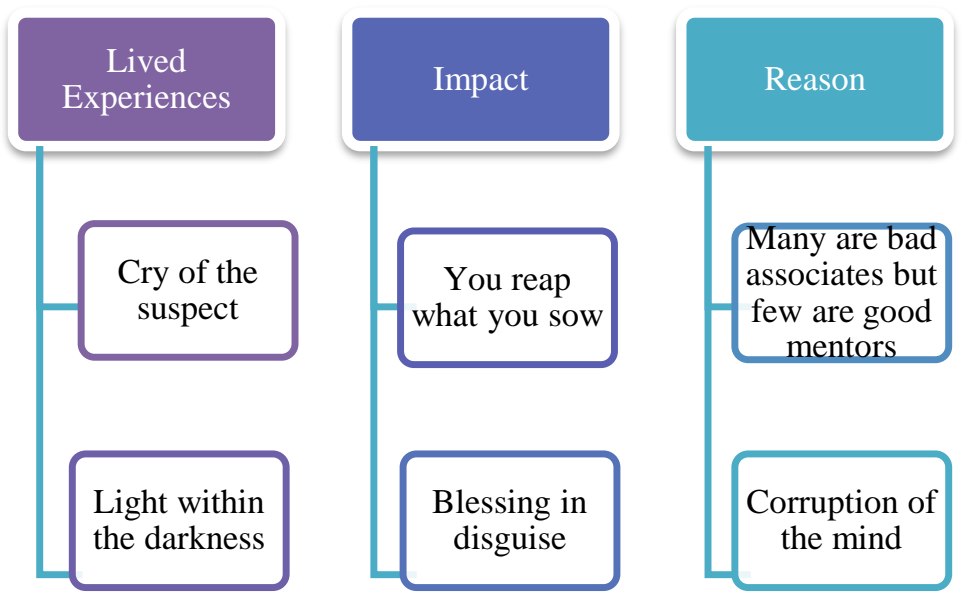

Figure 1. The Generated Themes of the Study

\section{The Lived Experiences of the Informants}

This sub-problem presented the positive and negative experiences of the informants on the pillars of the criminal justice system such as law enforcement, prosecution, court, correction, and community. After the interview, it was noted that the informants had encountered different types of abuse which include harassment, torture, brutality, planting of evidence, and other human rights violations mostly from the law enforcement pillar during arrest, search, and custodial investigation. The informants had also positive experiences and most of these were experienced inside the jail such as the opportunity to study, enough food supply, and attend mass and other religious activities. While the informants felt uncomfortable and some are hesitant to answer some questions, they remained firm on the sincerity of their responses in the course of the interview. Their responses showed the worst happening in their lives where some of them responded teary-eyed. Out of the responses from the informants, I created two themes.

\subsection{Cry Of The Suspect}

This theme answered the negative experiences of repeat offenders on the pillars of the criminal justice system particularly their undesirable experiences. Most of their undesirable or negative experiences happened during arrest and custodial investigation. During the interview, though the informants emphasized that not all police officers are bad, their faces showed the picture of ungratefulness and disrespect.

When I asked about his experience on law enforcement pillar, Informant 1 explained his suffering; in fact, he was saying this statement with sadness on his face:
Ginsakit, ginbutangan lang ko nila sang gin planteran lang ko nila tatlo ka putos nga shabu (FGD 1:SS2). [They hurt me and planted me 3 packs of shabu]

With teary eyes, Informant 1 continued sharing his experiences saying that:

Sa amon dah sa Brgy. Paraiso damo damo gid na da nga gin pang plantedan nila ina balang may ara lista nga posibilidad nga gagamit okon gabaligya (FGD 1:SS8). [In Barangay Paraiso, there were many of us who were in the list of possible buyers or pushers were being planted]

Informant 7 with great disappointment also shared his experiences. His statement goes like this:

Wala warrant of arrest bisan search warrant wala tapos nagdala sila drugs kag naghambal sila nga gabaligya ko. Kasakit kayo batyagon sir nga na lulong ka na sa bisyo amhon ka pa na (IDI 1:SS8). [There was no warrant of arrest even search warrant and then they brought up drugs saying I was selling those, it really hurts that you were addicted to that vices and was treated in that way]

With full of emotion, Informant 8 also shared his experiences telling this:

Nalabyan ko nila sa dalan, ti waay kaman guro krimen kung ara kalang sa dalan di bala? Ti galing amo pana ang kapait kay ging haras pako nila. wala man ko nila na kwaan ila man lang to ging butang sa akon tapos ging dala ko nila sa balay tapos nag conduct sila search peru ging admit ko sir nga gagamit ko (IDI 2:SS1). [They passed through me at the road then arrested me, the worst is, when they can't find anything from me, they put evidence on me and brought me to my house and then search. Though I admit that I used drugs]

Further, Informant 9 experienced the same fate. With an angry voice he narrated this:

Gi purungan, gitakluban ko nilag kaldero gibaklid ko nila sa posas, gikadinahan akong tiil gibastrok ko nilag maayu sa armalite, gipadolan ko nila dri sa likod di naku kakita unya gipa buthan ko nila ana ko grabi, hing rason naku nila, ing ani naman lang sir inyuha kung wala ko kahibaw sa natabo patya nalang ko sir(IDI 3:SS1). [I was blindfolded, they covered my head with a pot, handcuffed at the back, my feet were chained, hit me with an armalite at the back for several times, paddled me at my back until I can't see anything and they fired at me. I reasoned out already that I don't know anything and told them that it's better if they would just kill me]

Some of the informants also shared their negative experiences from the correction pillar just like the following when asked about their experiences in the BJMP. With full honesty, Informant 8 replied saying this statement: Diri sir ang malain di usually ang bully (IDI 2:SS5). [Here sir, the usual problem is bullying] 
A sense of unhappiness was seen while Informant 9 shared his undesirable experiences. His statement goes like this:

Ang naagian naku sa BJMP kapigadohon ug sa hirap sa pamilya sige tag consomisyon (IDI 3:SS4). [I experienced poverty, burden for my family and depression inside the BJMP]

\subsection{Light Within The Darkness}

The theme was created based on the responses of the participants. Informant 8 when asked about his positive experiences inside the BJMP, happily, he replied saying:

Ang mga personnel di sir okay man lang di sir nang makatawo man di ang personnel labi nagid ang warden di namon sir di man sa gusto nga magbinorong kami di nga mga piniriso ang ginapabatyag yaman lang pud nga daw ara lang kami sa amon panimalay bala (IDI 2:SS5). [For me sir, the personnel are nice especially our warden, he doesn't want us to be bored as prisoners, they are treating us like we are in our home sir]

When asked about the same question, Informant 10 replied with gratitude saying:

Ok ra pod sir maayo ra pod sir nagpasalamat gyud ko sa bureau pud nga naghatod para maka eskwela pod mi para naku magpasalamat gyud ko (IDI 4:SS5). [It's just okay sir, I'm really thankful with the bureau for sending me to school. For me, I'm really thankful]

Further, Informant 10 continued sharing with a feeling of satisfaction telling me this:

Ok raman kay katong nagkasakit ko kay hapoon man ko sir gitabang rapod ko nila (IDI 4:SS6). [It's just fine because when I was sick with asthma they helped me]

The researchers have a strong desire to know the experiences of the repeat offenders particularly their negative experiences in the pillars of the criminal justice system. During the period of my interview, most of them shared the same experiences such as they were the victim of police brutality, harassment, planting of evidence, and other forms of human rights violations. Although not all, most of these undesirable experiences were done during arrest and custodial investigation by the law enforcement pillar. However, there were also but only a few undesirable experiences by the informants in court and correction pillars such as mocking and bullying. These experiences may find support from deterrence theory [4] which states that deterrence theory has been expanded to include extralegal punishments (shaming, community service, etc.). To deter criminals police officers were using extra-legal punishments such as physical contact and harassment of offenders. This was supported also by [47] which states that the behavior of police officers is based on the premise that police behavior is influence by the social dynamics of police-citizen encounters. For example, Donald black's sociological theory of law holds that "the quantity of law" is influenced by the social attributes of concerned partiesvictims and suspects, or plaintiffs and defendants as well as the agents of social control themselves. In addition, the above theme was further supported by the study of [48] which states that Akers' social learning theory posits that peer associations, attitudes, reinforcement, and modeling are predictors of delinquency and crime in general. It seeks to determine if the theory can account for police deviance. Data from a random sample of Philadelphia police officers are used to examine how officer attitudes and perceptions of peer behavior are related to citizen complaints of police misconduct. Findings suggest that social learning theory provides a useful explanation of police misconduct. Furthermore, according to [49] conflict theory stipulates that strategies of crime control regulate threats to the interests of dominant groups. Measures of the presence of threatening people (percent black, percent Hispanic [in the Southwest], and majority/minority income inequality) were related positively to average annual civil rights criminal complaints. Lastly, the order maintenance policing strategies have negative implications for police legitimacy and crime control efforts via their potential to damage citizens' views of procedural justice [50].

Aside from their undesirable experiences, I was also very eager to know their desirable or positive experiences. After the interview, most of them shared the same experiences. The light within the darkness explained that despite the misfortune of the informants and while they were in the darkness they still have hope, they could still felt that they are part of the world. Some of them were given food by the law enforcement pillar during the custodial investigation but most of their desirable experiences happened in the correction pillar such as they were sent to school, hospitalized, given enough food supply, and were treated well. These positive experiences of the informants may find support from the Social Bond theory [7]. According to Hirschi, we are moral beings to the extent we are social beings. The social bond essentially refers to the connection between the individual and society. In addition, the above theme was further supported by the study from the reformative theory of punishment [51]. According to this theory, the object of punishment should be to bring about the moral reform of the offender. He must be educated and taught some art or industry during the period of his imprisonment so that he may be able to start his life again after his release from jail. Further, the above theme may find support also from the Good Lives Model (GLM) of [52] which states that the Good Lives Model (GLM) of offender rehabilitation is a strength-based approach by its responsiveness to offenders' core aspiration and interests, and its aim of providing them with the internal and external resources to live rewarding and offense-free lives. Finally, this theme may find support also from [53] which proposes a positive therapeutic approach based on the concept of the actualizing tendency as the motivational force for optimal human development and its stress in promoting offender well-being and its overall constructive orientation to correctional interventions, although it was developed independently of this perspective.

\section{The Impacts of Incarceration to the Informants}

This sub-problem showed the undesirable or the negative and the desirable or positive impacts of incarceration on the 
lives of informants. After the interview, it was noted that not only the offenders themselves had suffered the negative impact of incarceration but also their families and relatives. It was noted that despite their suffering, they had also a positive experience with the effects of incarceration particularly to their relationship with God, and the realization of their wrongdoings, and the importance of family. The following responses of the participants were based on their lived experiences. I created 2 emergent themes out from the responses of the informants.

\subsection{You Reap What You Sow}

This theme was created based on the responses of the informants. This showed the undesirable effects of incarceration on the lives of the informants. When asked how people treated him, Informant 3 shared his experiences with a deep feeling of regret. His statement goes like this:

Lain na sir kay daw may gap na sila saakon amo na halin ka sa prisohan kay amo na tungod nga nahadlok na sila medyo daw wala nagid sila gapalapit sa akon kis'a (FGD 3:SS4). [People treat me differently already since they know that I had committed a crime. They're afraid of me]

With a great feeling of pain and his tears was about to fall, Informant 3 shared this statement when asked about his family:

Sa akon pamilya daw wala nako sa ila tungod sa akon naglayo ko sa ila (FGD 3:SS5). [For my family, it seems I'm worthless to them because I am far from them]

Informant 4 experienced almost the same fate and feeling as Informant 3. While tears in his eyes falling, he shared this statement:

Sa akon pamilya daw wala nako sa ila tungod sa akon naglayo ko sa ila. Anom nako di kabulan wala gid nakalosot ok man lang wala man ko karapatan nga maglain sa ila kay sala ko man baton ko man (FGD 4:SS5). [I'm already six months here and still nobody visited me, but it's okay because in the first place it was my fault, that's why I don't have the right to hate them]

During the interview, it was noticed that Informant 10 suffered a great feeling of pain and remorse. With a very deep sense of sadness, he shared this statement:

Sakrispisyo sa amo ang pamilya, pigado sa gawas mo ari pa mohatod og kape mohatod og sabon ug dili pa dalawon mag ana pa usahay pero sa tinood lng sir mao gid sir pait gyud kaayo sir (IDI 4:SS2). [It was really a sacrifice for our family because we are really poor and they still need to visit me to bring something for me such as coffee, soap and more but sometimes they won't be allowed to get inside. Thinking of it is really hard sir]

Lastly, feeling bad about what had happened to him, Informant 5 shared this experience:

Amo lang na sir nabudlayan ka mangita trabaho (FGD 5:SS4). [I had a hard time to find a job, that's all Sir]

\subsection{Blessing in Disguise}

This theme emerged out from the responses of the informants. This theme presented the desirable or the positive impacts of incarceration on the lives of the informants. For instance, Informant 1 when asked, he courageously shared this statement with gladness:

Indi ko na kilala kun sin-o ko. Mas maayo nalang kag mapasalamat nalang ko gane nga mapriso ko liwat kay subong ko nakapamuklat sang athag (FGD 1:SS6). [I don't know myself anymore that's why I'm thankful that I'm in prison again because I was awaken]

At this time, during the interview, Informant 3 was feeling calm and serious. His statement goes like this:

Sa akon lang 60 or 70 percent makabulig sa tawo kay tungod ginrehab ka ara ka sa madumduman mo ang sala mo adlaw gab'e daw ma realize mo ang mga sala mo (FGD $3: \mathrm{SS} 8$ ). [For me, $60 \%-70 \%$ share would be helpful to the people]

Also, with humbleness, Informant 5 also shared saying this: Kabalo ka magpa umod kabalo ka magrespito sa kaparehas mo (FGD 5:SS3). [You know how to humble yourself and respect others]

Further, Informant 6 shared the impact of incarceration on his life by saying this statement with humility:

Ang pagpa-umod sa isig ka parihas init man ang ulo sa isa kalma ka (FGD 6:SS5). [Being patient even others are angry]

And lastly, Informant 8 shared with thankfulness to God despite his suffering. His statement goes like this:

Diri sir ang maayo di ya sa sulod mapinsaran mo ambi sir inang pareho ambi sina sir nga dako-dako gid ang kulang sa pamilya ko sir mo tapos amo na bala sang napriso ko di ang ga antos sa akon, akon lang pamilya ang mag dul'ong dul'ong akon lang asawa. dri sa sulod nakakilala ko diyos sir diri ko nabal'an nga tood-tood may ginoo amo ni gani guro ang natabo sa akon siguro leksyon nani nga para sakon nga kilalahon ko ang ginoo sir kay kabudlay nga layo ka sa pamilya mo ang kabataan kag asawa mo ang imo ginikanana ang paminsaron mo ga lupd nga ari ka di sa sulod wala ka kabalo di bala sir (IDI 2:SS4). [In here sir, the good thing inside is that you can think over some things like my shortcomings to my family sir and while I'm here, it's only my family, my wife who are sacrificing for me. Here I know God that He is real, maybe this is my lesson, to draw near to Him because it is really hard to be away from your family especially to your children, wife and parents, you are always thinking about them because you don't know what is happening to them because you are here]

Informant 8 continued sharing his experiences and if he will be into drugs again, replied this statement with firmness in his tone: 
Indi na sir for 23 years nga ara sa dulom subong ko nabatyagan nga tuig nga wala naku droga abi alcohol wala naman sigarilyo nalang ambi sir daw nagmayo na akun paminsarun sir nga daw ang akun pamatyag sir haw daw ok na ngaa ambi mabalik paku sa akun bisyo nabuhi ganeh ko nga wala nakasuyop for 1 year dayun amu nalang na guro dayun ang akun turning point e spend ang akun nabilin nga kabuhi sa akun pamilya, ginikanan ko (IDI $2: S S 7)$. [No sir, for 23 years in darkness only this year that I felt good since I don't take drugs and alcohol for almost one year, only smoking sir. Because of that, I am in a good state of mind and seems healthy, so why will I go back to my vices when I can live without taking drugs for 1 year. That is my turning point which is to spend my remaining time with my family and parents]

The researchers are concerned with the condition of the participants from the moment they were incarcerated and sent back again to the community particularly on the undesirable impact of incarceration on their life and family. During the conduct of the interview, they were emotional and felt regretful about their situation. After the interview, it was noted that most of the participants suffered a great undesirable impact, particularly on self and family relations. Most of them felt too much regret, burden, hardships, and depression. Their family ties were broken and experienced discrimination from the community. This study may find support from the Social Bond Theory of where the first element of the social bond is attachment [7]. This refers to the ties that an individual has to significant others such as family members. Attachment involves the degree to which the individual has affection or emotional ties to these people, identifies with them, and cares about their expectations. According to social bond theory, individuals with strong attachments are less likely to engage in deviant behavior. In addition to Hirschi's theory, this theme may find support also from the study of [54] which argued that an overreliance on incarceration as a formal control may hinder the ability of some communities to foster other forms of control because they weaken family and community structures. At the ecological level, the side effects of policies intended to fight crime by controlling individual behavior may exacerbate the problems they are intended to address. Thus, these communities may experience more, not less, social disorganization. And lastly, this theme is supported by the study of [55] which states that hundreds of thousands of children experience emotional turmoil each year as a result of the incarceration of a parent.

Being incarcerated does not mean that it's the end of the world. Sometimes, we just need a place or a situation to refresh our mind and realized our misbehavior but this process at times is not favorable to us. This theme emerged based on the responses of the participants, most of them considered incarceration as a blessing, an opportunity to realize their wrongdoings, a chance to learn, and more importantly an occasion to know God. This theme may find support from the Social Bond theory. [6] pointed out that if an individual believes in the given rules and knows what constitutes violating them, he would never engage in a deviant act. An individual will not be able to break the rules if that entails going against something he believes in. In addition, this is supported by [56] who said that social treatment, motivation to live, and the presence of the divine intervention made an ex-convict fully accept his/her life transformation for the better. Further, this theme is supported by the study of [57] who mentioned that if criminals are to be sent to prison to be transformed into good citizens by physical, intellectual, and moral training, prisons must be turned into comfortable dwelling places. Many incorrigible offenders are beyond the reach of reformative influences and with whom crime is not a bad habit but an instinct and they must be left to their fate in despair. But people criticize, the primary and essential end of criminal justice is deterrence and not reformation.

\section{The Reasons for Re-offending of the Informants} This sub-problem presented the reasons for the reoffending of the informants. After the interview, it was noted that most of the informants re-offend because of peer pressure, lack of family ties or guidance, alcohol, and drugs. From the responses of the informants, these themes had emerged. The following themes are as follows:

3.1 Many Are Bad Associates But Few Are Good Mentors This theme emerged from the responses of the informants and it showed that peer pressure and lack of family ties or guidance were the reasons for re-offending. Like Informant 1 when asked about his reason for re-offending, he replied this statement with a feeling of loneliness:

Te kay wala man ko may ginasaligan kag halin sang gamay pa pud daw nadala ko naman ni bala kay feeling nga daw wala kana pamilya, waay may gatudlo sakon kun ano ang mga maayo nga pamatasan (FGD 1:SS4). [Because I had no one to trust and from my childhood I felt that I have no family, no one taught me about the right attitude]

With a feeling of regret, Informant 3 shared also his reasons by saying this:

Barkada man gyapon sir, medyo nahagaran una una, una una ang tilaw tilaw lang sang pag abot sang punto tungod nga mahal, gin sudlan ang pagbaligya para malibri lang ang ano malibri lang sa kwan (FDG 3:SS5). [It was because of my friends sir. It seems like I was persuaded. At first, it was curiosity but later I joined in selling drugs so that I can use drugs for free]

I felt the burden and disappointment on the part of Informant 8 when he shared his reasons. His statement goes like this:

Tungod sa society damo mang gid ko mego sir mo amo na bala daw kabudlay man balibaran ang drugs sir mo, kung siling nga kabos ka gina tagaan kaman ka mego mo kwarta (IDI 8). [It was because of the society, I had many friends, sir, that's why it's really hard to say no to drugs because if you have nothing, they will give you money]

\subsection{Corruption Of The Mind}


The theme was formulated out from the responses of the informants. This theme gives us a picture of how vices such as drugs and alcohol corrupt the minds of the informants. Just like Informant 3 , he shared his reasons with sadness and feeling ungrateful saying this:

Una ga inom inom lang hasta nag abot ang punto ang drugs naka gamit ko amo sina nakahimo kami sala (FGD 3:SS1). [At first, it was just drinking of alcohol until it came to the point that I used drugs, that's why we were able to commit the crime]

Similarly, Informant 7 also shared his experience with full of unhappiness in her face when he was saying this:

Kay sa primero ko siling ko controlon ko magamit ko pero inang control lang bala pero nagtesting ko amo man gyapun pag testing indi ko macontrol sige sige asta nga nag adlaw adlaw ukon twice na (IDI 1:SS6). [At first, I said, I'll just control when I used it and I tried, but it's still the same, I still can't control it until such time that I was using it every day or even twice a day]

One of the themes that catch the attention and interest of the researchers why they conducted this study is to know the reasons for reoffending. The people around us especially our parents and friends are supposed to be our good mentors, but this was not in the case of the informants. Based on their responses, the reasons why the informants re-offend were mainly due to peer influence and lack of parental guidance. The result was supported by [6] where society's control over people prevents them from committing the crime. When there is a weak control, the likelihood of crime increases [58]. Therefore, an individual engaging in deviant behavior is the outcome of the weak or broken bond between the deviant and society. In addition, this theme may find support also from the study of [59] which reported that delinquent peer influences, antisocial personality traits, depression, and parents/guardians who use psychological abuse in intimate relationships were consistent risk factors for youth violence and aggression. Likewise, this theme may find support also from [60] which states that antisocial individuals choose to affiliate with deviant peers, and that affiliating with deviant peers is associated with an individual's delinquency, these complementary processes of selection and socialization operate in different developmental periods. And finally, this theme finds support from the study of [61] who found children with parents who are negatively involved or uninvolved in their lives are at a greater risk of becoming delinquents. Marital discord, conflict, and child abuse correlate with delinquency. Single-parent families produce more delinquent children than two-parent families. Although most juvenile delinquents do not commit crimes as adults, the important association between family life and criminal activity continues for adults. Other studies indicate that maintaining family ties while incarcerated and establishing good family situations upon release was associated with positive re-entry into the community and a reduction in recidivism.
After the interview, it was found that vices such as alcohol and drugs corrupted the minds of the offenders which pushed them to re-offend. Their minds were corrupted by the spirit of alcohol and drugs. This study may find support from the Social Bond theory. [6] argued that it is in people's nature to break the law, which is a result of them seeking gratification. In addition, this theme may find support from the study of [62] which states that data for Worcester in 1999 show that alcohol is noted as a contributory factor in $8 \%$ of recorded crime, but that the recorded role of alcohol is far higher for certain crime types: $48 \%$ of all harassment crimes; $36 \%$ of violent crime and $16 \%$ of criminal damage. Further, this theme finds support also from [63] who found that approximately 3 million violent crimes occur each year in which victims perceive the offender to have been drinking at the time of the offense. Two-thirds of victims who suffered violence by an intimate reported that alcohol had been a factor. For about 1 in 5 violent victimizations that involved perceived alcohol use by the offender, victims also reported they believed the offender to have been using drugs as well. Approximately half the incidents described by the investigating officer as alcohol-related were between offenders and victims who were intimates. Data showed that approximately 7 out of 10 alcohol-involved incidents of violence occurred in a residence. Among the data on drunk-driving arrests and fatal accidents are the numbers of such arrests. Trend analysis shows that over the last decade, rates of intoxication in fatal accidents have declined across every age group. Data on the use of alcohol by convicted offenders show that among the 5.3 million convicted offenders under the jurisdiction of corrections agencies in 1996, nearly 2 million (36 percent) were estimated to have been drinking at the time of the offense. Alcohol use at the time of the offense was commonly found among those convicted of public-order crimes. And finally, this theme may find support from [64] which reported that the dominant factors that predict whether a person relapses into crime are gender, age, criminal history, and family background. Moreover, problems with alcohol and/or drugs are also important risk factors.

\section{IMPLICATIONS OF THE STUDY}

Based on the findings, the following are recommended for practical applications: For the repeat offenders, it is recommended that to avoid re-offending, one should avoid friends who are in drugs and alcohol because based on the findings of this study, the influence of friends who are in drugs and alcohol are mostly the reasons for re-offending. For the repeat offender's family, it is recommended that emotional, psychological, including financial needs of family members especially those who were previously incarcerated, may be considered to avoid re-offending. Close family ties are also recommended for it is also one of the reasons why offenders re-offend. For the Local Government Unit, the government particularly the DILG in cooperation with the PNP shall find ways to prevent if not lessen police brutality, harassment, planting of evidence, and other human rights violations as well as may revisit their incentive system which focuses on the exemplary character of the police officers based on ethical standards. The construction of drug rehabilitation centers may be prioritized to cater to the needs of drug addicts and 
dependents, and programs that could discourage drinking of alcohol and taking of drugs may be initiated. The DSWD, in partnership with the correction pillar and the LGU, may work hand in hand for more effective and efficient rehabilitation programs specifically after the release of the offender to the community. Awareness about the responsibilities of the community as one of the pillars of criminal justice may be conducted to the community. Skills empowerment and livelihood programs are also suggested. For the correctional institutions specifically the BJMP, extending to the fullest of their rehabilitation programs and innovating more individualized programs particularly for the after-care program is recommended. Religious activities may be extended in time each day, free education until the tertiary level is also suggested. The following are recommended by the researchers for future studies: Firstly, the researchers suggest in-depth inquiry on the lived experiences of other types of repeat offending such as habitual delinquent, quasi-recidivist, and reiteration to know whether the results of these studies support or not the present study. Secondly, the researchers also suggest exploration of the lived experiences of the different pillars of the criminal justice system in handling repeat offenders. Knowing their lived experiences will validate the results of the present study. Lastly, the lived experiences of the repeat offender's family are also suggested for future study. Knowing their lived experiences will also support or deny the result of the present study particularly on the impact of incarceration of the repeat offender.

\section{REFERENCES}

[1] Payne, J. (2007). Recidivism in Australia: Findings and future research. Canberra: Australian Institute of Criminology.

[2] Durose, M. R., Cooper, A. D. \& Snyder, H. N. (2014). Recidivism of prisoners released in 30 states in 2005: Patterns from 2005 to 2010. Washington, DC: US Department of Justice, Office of Justice Programs, Bureau of Justice Statistics.

[3] Gibbs, XP. (1975). Crime, Punishment and deterrence. New York: Elsevier.

[4] Tittle, C., Botchkovar, E. \& Antonaccio, O. (2011). Criminal contemplation, national contect and deterrence. Journal of Quantitative Criminology, 27(2), 225-249.

[5] Stafford, M. C. \& Warr, M. (1993).A reconceptualization of general and specific deterrence. Journal of Research in Crime and Delinquency, 30(2), 123-135.

[6] Hirschi, T. (2002). Causes of delinquency Retrieved from http://www.Heritage.Org

[7] Hirschi, T. (1969).Causes of delinquency. Berkeley and Los Angeles: University of California Press.

[8] Shoemaker, D.J. (1996).Theories of delinquency: An examination of explanations of delinquent behaviour.3rd ed. New York: Oxford University Press.

[9] Akers, R. L. (1997). Criminological theories: Introduction and evaluation. (2nd ed.). Los Angeles: Rojtbury.

[10] Leonard, K.K.\& Decker, S.H. (1994). The theory of social control: Does it apply to the very young? Journal of Criminal Justice, 22, 89- 105 .

[11] Bernburg, J. G. \& Thorlindsson, T. (2005). Violent values, conduct norms, and youth aggression: A multilevel study in Iceland. Sociological Quarterly, 46(3), 457-478.

[12] Tannenbaum, F. (1938).Crime and community. Boston: Ginn.

[13] Becker, H. S. (1963). Outsiders: Studies in the sociology of deviance. New York: The Free Press.

[14] Bernburg, J. G., Krohn, M. D. \& Rivera, C. J. (2006). Official labeling, criminal embeddedness, and subsequent delinquency: A longitudinal test of labeling theory. Journal of Research in Crime and Delinquency, 43(1), 67-88.

[15] Nagin, D.\& Paternoster, R. (2000). Population heterogeneity and state dependence: State of the evidence and directions for future research. Journal of Quantitative Criminology, 16(2), 117-144.
[16] Blokland, A. A.\& Nieuwbeerta, P. (2005). The effects of life circumstances on longitudinal trajectories of offending. Criminology, 43(4), 1203-1240.

[17] Sampson, R. J., \& Laub, J. H. (2003).Desistance from crime over the life course.In Handbook of the life course, pp. 295-309.Springer, Boston, MA.

[18] Moffitt, T. E. (1993). Life-course-persistent and adolescence-limited anti-social behavior: A developmental taxonomy. Psychological Review, 100, 674-701. 24.

[19] Moffitt, T. E. (1994). Natural histories of delinquency.In E. Weitekamp, \& H. J. Kerner (Eds.), Cross-national longitudinal research on human development and criminal behavior. Dordrecht: Kluwer.

[20] Glaser Daniel. (1964). The Effectiveness of a Prison and Parole System. Indianapolis: BobbsMerrill.

[21] Lilly, Robert J., Cullen, Francis T. \& Ball, Richard A. (2007).Criminological Theory: Context and Consequences. Thousand Oaks, CA: Sage.

[22] Hairston, Creasie F. (1988). Family Ties During Imprisonment: Do They Influence Future Criminal Activity?. Federal Probation, 52:48-52.

[23] S. Xiong and B. Ye, "Analysis on the development path of smart city in the era of big data," in 2019 IEEE 4th International Conference on Big Data Analytics (ICBDA), 2019, pp. 177-181.

[24] Howser, James, Grossmn, Jody, \&Macdonald, Donald (1984). Impact of Family Reunion Program on Institutional Discipline. Journal of Offending Counseling, 8:27-36.

[25] Maruna, S. (2001). Making good. Washington, DC: American Psychological Association.

[26] Sampson, R. J.\& Laub, J. H. (2005). When prediction fails: From crime-prone boys to heterogeneity in adulthood. The Annals of the American Academy of Political and Social Science, 602(1), 73-79.

[27] Nieuwbeerta, P., Nagin, D. S.\& Blokland, A. A. (2009). Assessing the impact of first-time imprisonment on offenders' subsequent criminal career development: a matched samples comparison. Journal of Quantitative Criminology, 25(3), 227-257.

[28] Cale, J., Plecas, D., Cohen, I. M.\& Fortier, S. (2010). An exploratory analysis of factors associated with repeat homicide in Canada. Homicide Studies, 14(2), 159-180.

[29] Gove, W. R. (1985). The effect of age and gender on deviant behavior: A biopsychosocial perspective. Gender and the Life Course, 115-144.

[30] Baay, P., Liem, M. \& Nieuwbeerta, P. (2012). "Ex-Imprisoned Homicide Offenders: Once Bitten, Twice Shy?" The Effect of the Length of Imprisonment on Recidivism for Homicide Offenders. Homicide Studies, 16(3), 259-279.

[31] Neuilly, M. A., Zgoba, K. M., Tita, G. E.\& Lee, S. S. (2011). Predicting recidivism in homicide offenders using classification tree analysis. Homicide Studies, 15(2), 154-176.

[32] Trulson, C. R., Caudill, J. W., Haerle, D. R.\& DeLisi, M. (2012).Cliqued up: The postincarceration recidivism of young gang-related homicide offenders. Criminal Justice Review, 37(2), 174-190.

[33] Vries, A. M. \& Liem, M. (2011).Recidivism of juvenile homicide offenders. Behavioral Sciences \&The Law, 29(4), 483-498.

[34] Hanson, R. K. \& Bussiere, M. T. (1998).Predicting relapse: a metaanalysis of sexual offender recidivism studies. Journal of Consulting and Clinical Psychology, 66(2), 348.

[35] Firestone, P., Bradford, J. M., McCoy, M., Greenberg, D. M., Curry, S. \& Larose, M. R. (1998).Recidivism in convicted rapists. Journal of the American Academy of Psychiatry and the Law Online, 26(2), 185-200

[36] Kubrin, C. E. \& Stewart, E. A. (2006). Predicting who reoffends: The neglected role of neighborhood context in recidivism studies. Criminology, 44(1), 165-197.

[37] Adegoke, N. (2014). Preventing Recidivism in Nigerian Prisons through Provision of Educational Facilities: Experiencing National Open University of Nigeria Prisons' Special Centers. African Resources Development Journal, 17

[38] Dako-Gyeke, M. \& Baffour, F. D. (2016). We are like devils in their eyes: Perceptions and experiences of stigmatization and discrimination against recidivists in Ghana. Journal of Offender Rehabilitation, 55(4), 235-253.

[39] Međedović, J., Kujačić, D. \& Knežević, G. (2012). Personalityrelated determinants of criminal recidivism. Psihologija, 45(3), 277-294. 
[40] Harris, G. T., Rice, M. E. \& Cormier, C. A. (1991). Psychopathy and Violent Recidivism. Law and Human Behavior, 15(6), 625-637.

[41] Mallett, C. A., Fukushima, M., Stoddard-Dare, P. \& Quinn, L. (2013). Factors related to recidivism for youthful offenders. Criminal Justice Studies, 26(1), 84-98.

[42] Dela Fuente, J.A. (2021). Implementing inclusive education in the Philippines. College teacher experiences with deaf students. Issues in Educational Research, 31(1), 94-110. http://www.iier.org.au/iier31/dela-fuente.pdf

[43] Dela Fuente, J.A. (2019). Driving Forces of Students' Choice in Specializing Science: A Science Education Context in the Philippines Perspective. The Normal Lights, 13(2), 225-250.

[44] Silverman, D. (2011). Interpreting qualitative data: A guide to the principles of qualitative research.Thousand Oaks, CA:SAGE Publications Limited.

[45] Silverman, D. (2013). Doing qualitative research: A practical handbook.Thousand Oaks, CA: SAGE Publications Limited.

[46] Colaizzi, P. (1978). Psychological research as the phenomenologist's view it. In R. Vale \& M. King (Eds.). Existentialphenomenological alternatives for psychology. New York.

[47] Worden, R. E. (1995). TheCauses of Police Brutality: Theory and Evidence on Police Use of Force. In And Justice for All: Understanding and Controlling Police Abuse of Force,Edited by William A. Geller,Police Executive Research Forum.

[48] Chappell, A. T. \& Piquero, A. R. (2004). Applying social learning theory to police misconduct. Deviant Behavior, 25(2), 89-108.

[49] Holmes, M. D. (2000). Minority threat and police brutality: Determinants of civil rights criminal complaints in US municipalities. Criminology, 38(2), 343-368.

[50] Gau, J. M. \& Brunson, R. K. (2010). Procedural justice and order maintenance policing: A study of inner - city young men' $\mathrm{s}$ perceptions of police legitimacy. Justice Quarterly, 27(2), 255279

[51] Priya, T. (2014). Reformative Theory of Punishment. Retrieved from https://www.lawctopus.com/academike/reformative-theory-ofpunishment/.

[52] Ward, T. (2010). The good lives model of offender rehabilitation: Basic assumptions, etiological commitments, and practice implications. Offender supervision: New directions in theory, research and practice, 41-64.

[53] Joseph, S. \& Linley, P. A. (2004). Positive Therapy: A Positive Psychological Theory of Therapeutic Practice. In P. A. Linley \& S. Joseph (Eds.). Positive psychology in practice. Hoboken, NJ: John Wiley.

[54] Rose, D. R. \& Clear, T. R. (1998). Incarceration, social capital, and crime: Implications for social disorganization theory. Criminology, 36(3), 441-480.

[55] Fishman, S. H. (1983). The impact of incarceration on children of offenders. Journal of Children in Contemporary Society, 15(1), 89-99.

[56] Pansag, F. J. Rosaroso, R. C., Paradiang, L. A., Labasano, F. \& Lasala, G. (2016). Journey of an Ex-convict: From Conviction to Liberation. Asia Pacific Journal of Multidisciplinary Research, 4(2), 21-28.

[57] Salmond, R. (2014). Parliamentary question times: How legislative accountability mechanisms affect mass political engagement. The Journal of Legislative Studies, 20(3), 321-341.

[58] Cullen, F. T. \& Agnew, R. (2011). Criminological theory: Past to present: Essential Readings. Oxford University Press.

[59] Ferguson, C. J., San Miguel, C. \& Hartley, R. D. (2009). A multivariate analysis of youth violence and aggression: The influence of family, peers, depression, and media violence. The Journal Of Pediatrics, 155(6), 904-908.

[60] Monahan, K. C., Steinberg, L.\& Cauffman, E. (2009). Affiliation with antisocial peers, susceptibility to peer influence, and antisocial behavior during the transition to adulthood. Developmental Psychology, 45(6), 15-20.

[61] Wright, K. N. \& Wright, K. E. (1994). Family Life, Delinquency, and Crime: A Policymaker's Guide. Research Summary.US Department of Justice, Office of Justice Program, Office of Juvenile Justice and Delinquency Prevention.

[62] Bromley, R. D. \& Nelson, A. L. (2002). Alcohol-related crime and disorder across urban space and time: evidence from a British city. Geoforum, 33(2), 239-254.

[63] Greenfeld, L. A. (1998). Alcohol and crime. An Analysis of National Data on the Prevalence of Alcohol Involvement in Crime. Washington DC.
[64] Lebel, T. P., Burnett, R., Maruna, S. \& Bushway, S. (2008). The 'Chicken and Egg' of Subjective and Social Factors in Desistance from Crime. European Journal of Criminology, 5(2), 131-159. 